\title{
Effect of N, P, K and Cowdung on the Growth and Yield of Panchamukhi Kachu (Colocasia esculenta var. esculenta Schott.)
}

\author{
M. R. ISLAM ${ }^{1 *}$, M. MONIRUZZAMAN ${ }^{1}$ AND S. N. MOZUMDER ${ }^{2}$ \\ ${ }^{1}$ Agricultural Research Station, BARI, Raikhali, Chandraghona, Rangamati Hill District, Bangladesh \\ ${ }^{2}$ Hill Agricultural Research Station, BARI, Ramgarh, Khagrachhari Hill District, Bangladesh
}

Received 31 October 2005; received in revised form 19 June 2006; accepted 22 June 2006

\begin{abstract}
A field experiment was carried out during two consecutive cropping seasons of 2001-02 and 2002-03 at the Agricultural Research Station, Raikhali, Rangamati, to optimize fertilizer need for desirable yield of Panchamukhi Kachu (Colocasia esculenta var. esculenta Schott.). Fourteen combinations of treatments consisting four levels of $N\left(0,50,100\right.$ and $150 \mathrm{~kg} / \mathrm{ha}$ ), five levels of $\mathrm{P}_{2} \mathrm{O}_{5}(0,25,50,75$ and $100 \mathrm{~kg} / \mathrm{ha})$, four levels of $\mathrm{K}_{2} \mathrm{O}(0,60,120$ and $180 \mathrm{~kg} / \mathrm{ha})$ and three levels of cowdung $(0,10,20$ and 30 tha) were tested. A positive impact of each nutrient and cowdung application was observed on vegetative growth and fresh yield of the crop. The highest yield (average of two years) of 35.20 tha (54\% increase over control) was obtained with the application of $100 \mathrm{~kg}$ of $\mathrm{N}, 75 \mathrm{~kg} \mathrm{P}_{2} \mathrm{O}_{5}, 180 \mathrm{~kg}, \mathrm{~K}_{2} \mathrm{O}$ and 10t cowdung/ha. From the economic point of view, the combination of $100 \mathrm{~kg}$ of N, $75 \mathrm{~kg} \mathrm{P}_{2} \mathrm{O}_{5}$, $180 \mathrm{~kg} \mathrm{~K} \mathrm{~K}_{2} \mathrm{O}$ and 10 ton cowdung/ha was found to be the most suitable one which offered a gross return and gross margin of TK. 3.25 lakh/ha and Tk. 3.39 lakh/ha, respectively coupled with marginal rate of return as high as $3530.77 \%$.
\end{abstract}

Key words: Panchamukhi kachu, growth, yield.

\section{INTRODUCTION}

Panchamukhi Kachu (Colocasia esculenta var. esculenta Schott.), a perennial herb grown as annual, belonging to the family Araceae is a popular indigenous vegetable in Bangladesh. The leaves, petioles, corms and cormels are edible portion. The corm and cormels are rich in starch, which contain 17-25\% amylase (Bose and Som, 1986). Though at present the cultivation of the crop is mainly concentrated to the red soil areas of Madhupur and Bhawalghar including northeastern hilly region (Rashid, 1999), it has a great potentiality to grow all over the country. It is very popular to tribal people (Ahmed and Shahjahan, 1993). The crop is extensively grown in summer season and is considered as an important vegetable, particularly in the months of September to November when the supplies of other vegetable are scarce in the market (Mannan and Rashid, 1983). The requirement of fertilizer for any crop varies with the cultivars and soil types in different agro-ecological zones (Mitra et al., 1990). Adequate supply of, nitrogen, phosphorus and potash are essential for maximizing the yield of the crop. Like other tuber crop it has a great response to chemical and organic fertilizer and its yield is greatly influenced by the fertility of the soil (Ahmed and Rashid, 1975). Due to imbalance fertilization, the hilly farmers are being deprived of the

\footnotetext{
* Corresponding author: SO (Hort), ARS, BARI, Raikhali, Chandraghona, Rangamati Hill District- 4531.

(C) 2006, School of Agriculture and Rural Development, Bangladesh Open University. All rights reserved.
} 
economic benefit from this crop. Research information regarding suitable dose of $\mathrm{N}, \mathrm{P}, \mathrm{K}$ and cowdung for the satisfactory production of Panchamukhi Kachu is almost lacking in Bangladesh. The present study was therefore, undertaken to determine the suitable combination of $\mathrm{N}, \mathrm{P}$ and $\mathrm{K}$ along with cowdung in order to obtain satisfactory yield of Panchamukhi Kachu at the agroecological zone- 29 (AEZ- 29).

\section{MATERIALS AND METHODS}

The experiment was conducted in two consecutive cropping seasons of 2001-02 and 02-03 at the Hill Agricultural Research Station, Raikhali, Rangamati to find out the effect of N, P, K and cowdung on the growth and yield of Panchamukhi Kachu. The experimental field belongs to AEZ 29 and the soil was Piedmont plain having medium loamy to moderately fine textured (Sandy clay loam) (Zahirul, 1991) and low water holding capacity. The results of soil analysis before experiment was given in Table 1.

Table 1. Chemical properties of the soil of experiment plot

\begin{tabular}{lcc}
\hline \multirow{2}{*}{ Name of the properties } & \multicolumn{2}{c}{ Amount } \\
\cline { 2 - 3 } & $2001-02$ & $2002-03$ \\
\hline \hline Soil pH & 5.4 & 5.5 \\
OM (organic matter) & $1.48 \%$ & $1.51 \%$ \\
Total nitrogen $(\mathrm{N})$ & $0.078 \%$ & 0.075 \\
Available Phosphorus (P) & $8.0 \mu \mathrm{g} / \mathrm{g}$ & $8.5 \mu \mathrm{g} / \mathrm{g}$ \\
Available potassium (K) & $0.17 \mathrm{meq} / 100 \mathrm{~g}$ soil & $0.19 \mathrm{meq} / 100 \mathrm{~g}$ soil \\
\hline
\end{tabular}

The experiment was laid out in a RCB design with three replications. The unit plot size was $3 \times 3.2 \mathrm{~m}$. Fourteen combinations of treatment consisting four levels of $\mathrm{N}(0,50,100$, and 150 and $\mathrm{kg} / \mathrm{ha})$, five levels of $\mathrm{P}_{2} \mathrm{O}_{5}(0,25,50,75$ and $100 \mathrm{~kg} / \mathrm{ha})$, and four levels of $\mathrm{K}_{2} \mathrm{O}(0,60,120$, and 180 $\mathrm{kg} / \mathrm{ha})$ and three levels of cowdung $(0,10,20$ and $30 \mathrm{t} / \mathrm{ha})$ were used in the experiment.

The entire amount of cowdung and TSP and half of urea and MP were applied during land preparation. The rest of urea and MP were applied in three equal instalments at 30,50 and 70 days after planting. The planting materials (each cormel $50 \pm 5 \mathrm{~g}$ ) of local cultivars were placed (one seed/hill) under $5-7.5 \mathrm{~cm}$ in soil maintaining $60 \times 40 \mathrm{~cm}$ of spacing. Weeding, mulching, irrigation, etc were done as and when necessary. The crop was harvested when the pseudostem (succulent leaf sheath arise from underground rhizome) of the plant was almost dried. Data on yield and yield attributes were taken from 10 randomly selected plants from each plot. The plot yield was first recorded and then converted to per hectare yield. Length of leaf, leaf spread, plant heights, yields and yield attributes were calculated from the average of ten plants. The final data were compiled properly and analyzed statistically following the standard method. Economic analyses were done on the basis of prevailing market price of input and output. Economical analysis of different fertilizer combinations was done through partial budgeting and dominance analysis followed by marginal analysis of the cost undominated treatments as suggested by Perrins et al. (1979).

\section{RESULTS AND DISCUSSION}

Plant height was significantly influenced by different fertilizer treatments. Maximum plant height $\left(107.0 \mathrm{~cm}\right.$ in $2001-02,97.26 \mathrm{~cm}$ in $2002-03$ and $120.13 \mathrm{~cm}$ in pooled data) was obtained from $\mathrm{T}_{9}$ $\left(\mathrm{N}_{100} \mathrm{P}_{100} \mathrm{~K}_{120} \mathrm{Kg} / \mathrm{ha}\right.$ and Cowdung $10 \mathrm{t} / \mathrm{ha}$ ) treatment and minimum for the same was obtained from control $\left(\mathrm{T}_{1}=\mathrm{N}_{0} \mathrm{P}_{0} \mathrm{~K}_{0} \mathrm{Cd}\right)$ treatment in both the years and in pooled condition. Plant height increased with increased rate of nitrogen application (Table 2). Nitrogen application at the rate of 50,100 and $150 \mathrm{~kg} / \mathrm{ha}$ in presence of other nutrient elements gave $8.35 \%$ to $23.64 \%$ higher plant height over $\mathrm{N}$ control treatment, respectively. Plant height also increased with the increase of phosphorus application in both the years and pooled data. It showed statistically similar result among 25, 50, 75 and $100 \mathrm{~kg} / \mathrm{ha}$ dose of $P$ in the first year and pooled data but significantly different from $P$ control. Different levels of $P$ did not significantly influence plant height in the $2^{\text {nd }}$ year. Different levels of $\mathrm{K}$ also showed same trend like $\mathrm{P}$ in the $2^{\text {nd }}$ year and in pooled result. Application of cowdung @ 10t/ha in presence of other nutrient elements and 20 and $30 \mathrm{t} / \mathrm{ha}$ alone 
also significantly produced higher plant than no cowdung $\left(T_{1}\right)$ in both the years and in pooled data. Base girth of the plant was not significantly influenced due to different fertilizer treatment in the first year but this parameter varied significantly in response to different fertilizer treatments in the $2^{\text {nd }}$ year and pooled data. Base girth was not significantly affected by different doses of $\mathrm{N}, \mathrm{P}$ and $\mathrm{K}$ and cowdung, only significantly influenced by various dose of $P$ in pooled data. Number of leaves/hill was significantly influenced by different fertilizer treatments (Table 2). Maximum number of leaves (34.24 and 33.50/hill in 2001-02, 2002-03 and pooled data, respectively) was recorded from $\mathrm{T}_{12}$ treatment, which was statistically similar to $T_{4}, T_{5}, T_{9}$ and $T_{11}$. Number of leaves/hill increased significantly up to $100 \mathrm{~kg} \mathrm{~N} / \mathrm{ha}, 75 \mathrm{~kg} \mathrm{P} \mathrm{O}_{5} / \mathrm{ha}$ and $120 \mathrm{~kg} \mathrm{~K}{ }_{2} \mathrm{O} / \mathrm{ha}$. The number of leaves/hill at 100 $\mathrm{N}, 75 \mathrm{~kg} \mathrm{P} \mathrm{O}_{5}$ and $120 \mathrm{~kg} \mathrm{~K} \mathrm{O}_{2}$ /ha was at par with $150 \mathrm{~kg} \mathrm{~N}, 100 \mathrm{~kg} \mathrm{P}_{2} \mathrm{O}_{5}$ and $180 \mathrm{~kg} \mathrm{~K} \mathrm{O}_{2} / \mathrm{ha}$.

Table 2. Treatment combinations of different fertilizer (Anon., 1969)

\begin{tabular}{ccccc}
\hline Treatment & \multicolumn{4}{c}{ Treatment combinations } \\
\cline { 2 - 5 } & $\begin{array}{c}\mathrm{N} \\
(\mathrm{kg} / \mathrm{ha})\end{array}$ & $\begin{array}{c}{ }^{* *} \mathrm{P}_{2} \mathrm{O}_{5} \\
(\mathrm{~kg} / \mathrm{ha})\end{array}$ & $\begin{array}{c}{ }^{* *} \mathrm{~K}_{2} \mathrm{O} \\
(\mathrm{kg} / \mathrm{ha})\end{array}$ & $\begin{array}{c}\mathrm{CD} \\
(\mathrm{t} / \mathrm{ha})\end{array}$ \\
\hline \hline $\mathrm{T}_{1}$ & 0 & 0 & 0 & 0 \\
$\mathrm{~T}_{2}$ & 0 & 75 & 120 & 10 \\
$\mathrm{~T}_{3}$ & 50 & 75 & 120 & 10 \\
$\mathrm{~T}_{4}$ & 100 & 75 & 120 & 10 \\
$\mathrm{~T}_{5}$ & 150 & 75 & 120 & 10 \\
$\mathrm{~T}_{6}$ & 100 & 0 & 120 & 10 \\
$\mathrm{~T}_{7}$ & 100 & 25 & 120 & 10 \\
\hline Note: ${ }^{* *} \mathrm{P}_{2} \mathrm{O}_{5} \times 0.44=\mathrm{P}$ and ${ }^{* * *} \mathrm{~K}_{2} \mathrm{O} \times 0.83=\mathrm{K}$
\end{tabular}

\begin{tabular}{ccccc}
\hline Treatment & \multicolumn{4}{c}{ Treatment combinations } \\
\cline { 2 - 5 } & $\mathrm{N}$ & ${ }^{* *} \mathrm{P}_{2} \mathrm{O}_{5}$ & ${ }^{* * *} \mathrm{~K}_{2} \mathrm{O}$ & $\mathrm{CD}$ \\
& $(\mathrm{kg} / \mathrm{ha})$ & $(\mathrm{kg} / \mathrm{ha})$ & $(\mathrm{kg} / \mathrm{ha})$ & $(\mathrm{t} / \mathrm{ha})$ \\
\hline \hline $\mathrm{T}_{8}$ & 100 & 50 & 120 & 10 \\
$\mathrm{~T}_{9}$ & 100 & 100 & 120 & 10 \\
$\mathrm{~T}_{10}$ & 100 & 75 & 0 & 10 \\
$\mathrm{~T}_{11}$ & 100 & 75 & 60 & 10 \\
$\mathrm{~T}_{12}$ & 100 & 75 & 180 & 10 \\
$\mathrm{~T}_{13}$ & 0 & 0 & 0 & 20 \\
$\mathrm{~T}_{14}$ & 0 & 0 & 0 & 30 \\
\hline
\end{tabular}

Weight of cormel/plant varied significantly in response to different fertilizer treatments (Table 3 ). Maximum weight of cormel (511.0g/plant in 2001-02) was recorded from $\mathrm{T}_{11}$ treatment whereas in 2002-03 and in pooled data $T_{12}$ treatment produced the highest cormel weight $(437.3 \mathrm{~g} / \mathrm{plant}$ in 2003-03 and 442.15g/plant in pooled data. Different fertilizer treatments resulted in an increase in cormel weight/plant ranging from $29.27 \%$ to $55.20 \%$ over control $\left(T_{1}\right)$ treatment in pooled condition. Weight of cormel/plant increased gradually with the increase of nitrogen, phosphorus and potassium levels. Applications of cowdung @ 20 \& 30t/ha did not have significant influences on cormel weight/plant. Different fertilizer treatments significantly influenced weight of corm/plant. The highest weight of corm /plant (804g in 2001-02. 864.0g in 2002-03 and 825.0g in pooled data) was recorded from the $T_{12}$ treatment and minimum values for the same from $T_{1}$ treatment. Different treatment combinations registered $34.41 \%$ to $53.80 \%$ higher corm weight/plant over control treatments in pooled data of two years. In both the years and pooled data corm weight/plant increased significantly with the increase of $\mathrm{N}$ levels up to $100 \mathrm{~kg} / \mathrm{ha}$ beyond which corm weight declined. Corm weight/hill increased up to the highest level of $\mathrm{P}$ and $\mathrm{K}$ levels. Number of cormel/hill was significantly affected by different fertilizer treatments. The highest number of cormel/hill (pooled) (13.10) was observed from $T_{12}$ treatment closely followed by $T_{4}, T_{5}, T_{7}, T_{8}, T_{9}, T_{11}$ and $T_{14}$ treatments. Maximum fresh yield/plant $(1251.0 \mathrm{~g}$ in 2001-02, $1283.0 \mathrm{~g}$ in $2002-03$ and $1267.0 \mathrm{~g}$ in pooled data) was obtained from $\mathrm{T}_{12}\left(\mathrm{~N}_{100} \mathrm{P}_{75} \mathrm{~K}_{180} \mathrm{~kg} / \mathrm{ha}\right.$ and $\left.\mathrm{cd}_{10} \mathrm{t} / \mathrm{ha}\right)$ treatment that was at par with $T_{3}, T_{4}, T_{5}, T_{7}, T_{8}, T_{9}, T_{10}, T_{11}$ and $T_{14}$ of 2001-02, $T_{4}, T_{5}, T_{8}$ and $T_{10}$ of 2002-03 and $T_{4} T_{5}, T_{7}, T_{8}, T_{9}$, and $T_{11}$ in pooled data. The pooled data showed that different fertilizer treatments resulted in a increase in fresh yield/hill ranging from $33.57 \%$ to $54.31 \%$ over control treatments. In 2001-02, fresh yield /hill increased with the increase of $\mathrm{N}$ up to the highest levels $(150 \mathrm{~kg} / \mathrm{ha})$. But in 2002-03 and pooled data, the yield/hill increased up to $100 \mathrm{~kg} / \mathrm{ha}$ beyond which yield declined. Fresh yield/hill increased significantly with the increase of $P$ levels up to $75 \mathrm{~kg} / \mathrm{ha}$ beyond which it declined in both the years and pooled data. But the fresh yield /hill of the crop increased up to the highest levels of $\mathrm{K}(180 \mathrm{~kg} / \mathrm{ha})$. Independent applications of cowdung @ 30t/ha performed significantly better than $20 \mathrm{t} / \mathrm{ha}$ in respect of fresh yield/hill in the $2^{\text {nd }}$ year and pooled data. Fresh yield /ha of Panchamukhi Kachu was significantly influenced by the application of N, P, K and cowdung (Table 3). Nitrogen application increased yield/ha significantly showing a linear response in the Ist year and pooled data (Table 3). The highest yield of 35.20t/ha (pooled of two years) was 
recorded with the treatment $T_{12}$ that was statistically at per with $T_{4}, T_{5}, T_{6}, T_{7}, T_{8}, T_{9}$ and $T_{11}$. The fresh yield increased with the increase of $\mathrm{N}$ up to $150 \mathrm{~kg} / \mathrm{ha}$. Identical yields of 32.57 and $32.84 \mathrm{t} / \mathrm{ha}$ at 100 and $150 \mathrm{~kg} \mathrm{~N} / \mathrm{ha}$, respectively, resulted that $\mathrm{N}$ application had certain optimum range beyond which profitable yield is not increased. Application of $\mathrm{P}$ significantly increased fresh yield of Panchamukhi Kachu up to the highest level $100 \mathrm{~kg} \mathrm{P} \mathrm{O}_{5} / \mathrm{ha}$ in the first year but in the 2002-03 and pooled data, increased up to $75 \mathrm{~kg} / \mathrm{ha}$. The yield differences among 25, 50, 75 and $100 \mathrm{~kg} \mathrm{P} \mathrm{P}_{2} \mathrm{O}_{5} / \mathrm{ha}$ was statistically identical in both years as well as in pooled data.. The pooled data showed that the yield at $75 \mathrm{~kg} \mathrm{P} \mathrm{P}_{5}$ /ha was significantly different from no $\mathrm{P}_{2} \mathrm{O}_{5}$. Fertilization of $\mathrm{K}$ resulted in gradual increase in fresh yield of Panchamukhi Kachu up to the highest level of applied $\mathrm{K}(180 \mathrm{~kg} / \mathrm{ha})$ in both years as well as in pooled data (Table 3).

Table 3. Effect of N, P, K and Cowdung on the growth parameters of Panchamukhi Kachu

\begin{tabular}{cccccccccc}
\hline & \multicolumn{3}{c}{ Plant height $(\mathrm{cm})$} & \multicolumn{3}{c}{ Base girth $(\mathrm{cm})$} & \multicolumn{3}{c}{ Leaf number/hill } \\
\cline { 2 - 10 } Treatment & $2001-02$ & $2002-03$ & Pooled & $2001-02$ & $2002-03$ & Pooled & $2001-02$ & $2002-03$ & Pooled \\
\hline \hline $\mathrm{T}_{1}$ & $82.3 \mathrm{~cd}$ & $46.19 \mathrm{~d}$ & $64.25 \mathrm{f}$ & $19.33 \mathrm{abc}$ & $14.38 \mathrm{~d}$ & $16.84 \mathrm{c}$ & $16.12 \mathrm{c}$ & $19.29 \mathrm{~d}$ & $17.71 \mathrm{c}$ \\
$\mathrm{T}_{2}$ & $89.8 \mathrm{bcd}$ & $75.93 \mathrm{c}$ & $82.85 \mathrm{de}$ & $22.20 \mathrm{ab}$ & $20.57 \mathrm{bc}$ & $21.39 \mathrm{bc}$ & $21.60 \mathrm{~b}$ & $25.85 \mathrm{c}$ & $23.73 \mathrm{~b}$ \\
$\mathrm{~T}_{3}$ & $93.3 \mathrm{a}-\mathrm{d}$ & $91.19 \mathrm{ab}$ & $92.25 \mathrm{bc}$ & $23.70 \mathrm{a}$ & $22.22 \mathrm{abc}$ & $22.96 \mathrm{ab}$ & $24.19 \mathrm{~b}$ & $28.95 \mathrm{bc}$ & $26.57 \mathrm{~b}$ \\
$\mathrm{~T}_{4}$ & $100.7 \mathrm{ab}$ & $94.80 \mathrm{ab}$ & $97.75 \mathrm{ab}$ & $24.9 \mathrm{a}$ & $25.40 \mathrm{abc}$ & $25.15 \mathrm{ab}$ & $31.98 \mathrm{a}$ & $33.42 \mathrm{ab}$ & $32.70 \mathrm{a}$ \\
$\mathrm{T}_{5}$ & $107.6 \mathrm{a}$ & $95.33 \mathrm{ab}$ & $101.46 \mathrm{a}$ & $22.7 \mathrm{ab}$ & $25.02 \mathrm{abc}$ & $23.86 \mathrm{ab}$ & $32.22 \mathrm{a}$ & $33.77 \mathrm{ab}$ & $32.99 \mathrm{a}$ \\
$\mathrm{T}_{6}$ & $80.8 \mathrm{~d}$ & $84.73 \mathrm{abc}$ & $82.76 \mathrm{de}$ & $19.6 \mathrm{abc}$ & $23.35 \mathrm{abc}$ & $21.48 \mathrm{bc}$ & $24.12 \mathrm{~b}$ & $25.21 \mathrm{c}$ & $24.66 \mathrm{~b}$ \\
$\mathrm{~T}_{7}$ & $96.5 \mathrm{a}-\mathrm{d}$ & $89.47 \mathrm{ab}$ & $92.99 \mathrm{abc}$ & $22.5 \mathrm{ab}$ & $25.53 \mathrm{abc}$ & $24.02 \mathrm{ab}$ & $24.50 \mathrm{~b}$ & $25.24 \mathrm{c}$ & $24.69 \mathrm{~b}$ \\
$\mathrm{~T}_{8}$ & $98.1 \mathrm{abc}$ & $95.93 \mathrm{a}$ & $97.02 \mathrm{abc}$ & $24.3 \mathrm{a}$ & $26.40 \mathrm{ab}$ & $25.35 \mathrm{a}$ & $24.15 \mathrm{~b}$ & $25.60 \mathrm{c}$ & $25.05 \mathrm{~b}$ \\
$\mathrm{~T}_{9}$ & $107.0 \mathrm{a}$ & $97.26 \mathrm{a}$ & $102.13 \mathrm{a}$ & $26.4 \mathrm{a}$ & $26.87 \mathrm{a}$ & $26.14 \mathrm{a}$ & $32.08 \mathrm{a}$ & $33.52 \mathrm{ab}$ & $32.80 \mathrm{a}$ \\
$\mathrm{T}_{10}$ & $89.2 \mathrm{bcd}$ & $75.53 \mathrm{c}$ & $82.37 \mathrm{de}$ & $25.8 \mathrm{a}$ & $23.76 \mathrm{abc}$ & $24.78 \mathrm{ab}$ & $24.45 \mathrm{~b}$ & $25.55 \mathrm{c}$ & $25.00 \mathrm{~b}$ \\
$\mathrm{~T}_{11}$ & $98.2 \mathrm{abc}$ & $88.67 \mathrm{ab}$ & $93.43 \mathrm{abc}$ & $25.2 \mathrm{a}$ & $25.00 \mathrm{abc}$ & $25.10 \mathrm{ab}$ & $31.90 \mathrm{a}$ & $33.33 \mathrm{ab}$ & $32.61 \mathrm{a}$ \\
$\mathrm{T}_{12}$ & $103.8 \mathrm{ab}$ & $96.13 \mathrm{a}$ & $99.97 \mathrm{ab}$ & $23.7 \mathrm{ab}$ & $26.63 \mathrm{a}$ & $25.17 \mathrm{ab}$ & $32.76 \mathrm{a}$ & $34.24 \mathrm{a}$ & $33.50 \mathrm{a}$ \\
$\mathrm{T}_{13}$ & $83.9 \mathrm{~cd}$ & $74.53 \mathrm{c}$ & $79.22 \mathrm{e}$ & $24.3 \mathrm{a}$ & $20.07 \mathrm{c}$ & $22.50 \mathrm{ab}$ & $24.01 \mathrm{~b}$ & $25.09 \mathrm{c}$ & $24.55 \mathrm{~b}$ \\
$\mathrm{~T}_{14}$ & $94.1 \mathrm{a}-\mathrm{d}$ & $82.80 \mathrm{bc}$ & $88.45 \mathrm{~cd}$ & $23.7 \mathrm{ab}$ & $24.40 \mathrm{abc}$ & $24.05 \mathrm{ab}$ & $24.05 \mathrm{~b}$ & $25.13 \mathrm{c}$ & $34.59 \mathrm{~b}$ \\
\hline $\mathrm{CV}(\%)$ & 7.21 & 5.96 & 4.00 & 14.71 & 9.53 & 8.09 & 4.63 & 5.19 & 3.21 \\
\hline
\end{tabular}

Note: Pooled data of 2001-2002 and 2002- 03. Means followed by uncommon letters in a column are significantly different from each other at $5 \%$ level of probability by DMRT

The variation of yield from 27.10 to $33.52 \mathrm{t} / \mathrm{ha}$ is due to the application of different levels of $\mathrm{K}$ fertilizer. Independent application of Cowdung @ 30t/ha gave higher fresh yield than 20t/ha cowdung in both years. The average yield increase over control due to the application of individual nutrients is shown in Table 5 . Fresh yield increased progressively with $\mathrm{N}$ rates up to $150 \mathrm{~kg} / \mathrm{ha}$. Application of 50,100 and $150 \mathrm{~kg} \mathrm{~N} / \mathrm{ha}$ increased by $15.96,25.42$ and $26.05 \%$ over control, respectively. It appears that application of $100 \mathrm{~kg} \mathrm{~N} / \mathrm{ha}$ might be optimum for maximizing the fresh yield of Panchamukhi Kachu. Application of phosphorus @ 25, 50, 75 and $100 \mathrm{~kg} \mathrm{P}_{2} \mathrm{O}_{5} / \mathrm{ha}$ increased fresh yield by 12.35, 14.06, 15.93 and $12.27 \%$ over control, respectively (Table 4). K application @ $180 \mathrm{~kg} \mathrm{~K} \mathrm{~K}_{2} \mathrm{O} / \mathrm{ha}$ resulted maximum increase $(23.01 \%)$ of yield. Cowdung application @ 30t/ha gave higher yield increase (41.98) of the crop than 20t/ha (Table 4).

The partial budget analysis of fertilizer use indicates that the gross return (GR) increased with the increase of N, P and K fertilizer up to 150,75 and $180 \mathrm{~kg} /$ ha respectively (Table 5) Maximum gross return of Tk. 352.0 thousand, Tk. 328.7 thousand, Tk. 325.7 thousand/ha achieves from treatment $\mathrm{T}_{12}, \mathrm{~T}_{5}$ and $\mathrm{T}_{4}$ respectively. Similar trend was also observed in respect of gross margin. The highest net return (Tk. 294.0 thousand/ha) was obtained from $T_{12}$ treatment closely followed by $T_{5}$ and $T_{4}$ treatment. Dominance analysis showed that $T_{2}, T_{3}, T_{7}, T_{8}, T_{9} T_{10}, T_{13}$ and $T_{14}$ were dominated by cost factor and $T_{1}, T_{4}, T_{5}, T_{6}, T_{11}$ and $T_{12}$ were cost undominated. Marginal analyses of the cost undominated treatments (Table 6 ) reflected that the gross margin could be increased up to Tk. 294.0 thousand/ha along with a high marginal rate of return of $3530.77 \%$ through increased investment for fertilizer up to Tk. 13.0 thousand $\left(\mathrm{T}_{12}\right)$ (Table 7$)$. 
Table 4. Effect of $N, P, K$ and Cowdung on the fresh yield of corm and cormel of Panchamukhi Kachu

\begin{tabular}{|c|c|c|c|c|c|c|c|c|c|c|c|c|c|}
\hline \multirow[b]{2}{*}{ 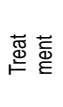 } & \multicolumn{3}{|c|}{ Weight of cormel/hill (g) } & \multicolumn{3}{|c|}{ Weight of corm/hill (g) } & \multicolumn{3}{|c|}{ Fresh yield /hill (g) } & \multirow{2}{*}{$\begin{array}{c}\text { Cormel } \\
\text { /hill } \\
(\text { No. })^{*}\end{array}$} & \multicolumn{3}{|c|}{ Fresh yield (t/ha) } \\
\hline & $\begin{array}{c}2001 \\
-02\end{array}$ & $\begin{array}{c}2002- \\
03\end{array}$ & Pooled & $\begin{array}{c}2001 \\
-02\end{array}$ & $\begin{array}{c}2002- \\
03\end{array}$ & Pooled & $\begin{array}{c}2001- \\
02\end{array}$ & $2002-03$ & Pooled & & $\begin{array}{c}2001- \\
02\end{array}$ & $\begin{array}{c}2002- \\
03\end{array}$ & Pooled \\
\hline $\mathrm{T}_{1}$ & $210 d$ & $186.0 f$ & $198.0 \mathrm{e}$ & $475 d$ & $287.3 \mathrm{~g}$ & $381.15 \mathrm{~g}$ & $685 d$ & $472.7 \mathrm{~h}$ & $578.85 f$ & $5.85 \mathrm{~g}$ & $19.00 \mathrm{~d}$ & $13.13 f$ & $16.15 \mathrm{~g}$ \\
\hline $\mathrm{T}_{2}$ & $304 \mathrm{bcd}$ & $280.7 \mathrm{e}$ & $292.35 d$ & $597 \mathrm{~cd}$ & $565.3 \mathrm{ef}$ & $581.15 f$ & $901 \mathrm{c}$ & $846.0 f g$ & $873.5 \mathrm{e}$ & $9.05 f$ & $25.05 \mathrm{c}$ & $23.50 \mathrm{de}$ & $24.28 f$ \\
\hline $\mathrm{T}_{3}$ & $326 \mathrm{bcd}$ & $326.7 \mathrm{cde}$ & $326.35 \mathrm{~cd}$ & $740 a b c$ & $687.3 \mathrm{~cd}$ & $713.65 \mathrm{bcd}$ & $1066 a b c$ & 1014.0cde & $1040.0 \mathrm{bcd}$ & $10.75 \mathrm{def}$ & $29.61 \mathrm{c}$ & $28.17 a-d$ & $28.89 \mathrm{~b}-\mathrm{e}$ \\
\hline $\mathrm{T}_{4}$ & $353 a-d$ & $398.7 a b c$ & $269.43 \mathrm{bcd}$ & $801 a$ & $814.0 \mathrm{ab}$ & $807.50 a b c$ & $1154 a b$ & 1213.0ab & $1183.5 \mathrm{abc}$ & $11.79 a-d$ & $32.06 \mathrm{ab}$ & $33.68 \mathrm{a}$ & $32.57 \mathrm{abc}$ \\
\hline$T_{5}$ & $435 a b c$ & 377.3a-d & $406.15 \mathrm{abc}$ & $766 \mathrm{ab}$ & 768.0abc & $767.0 a-d$ & $1201 a$ & 1146.0abc & $1173.5 a$ & $12.77 a b$ & $33.36 \mathrm{a}$ & $31.83 \mathrm{ab}$ & $32.84 a b$ \\
\hline $\mathrm{T}_{6}$ & $370 a-d$ & $280.0 \mathrm{e}$ & $325.0 \mathrm{~cd}$ & $608 \mathrm{~cd}$ & $720.0 b c$ & $664.0 \mathrm{de}$ & $978 b c$ & 993.3def & $985.65 d$ & $9.69 \mathrm{ef}$ & $27.17 b c$ & $27.59 a-e$ & 27.38def \\
\hline $\mathrm{T}_{7}$ & $421 a b c$ & $384.0 \mathrm{a}-\mathrm{d}$ & $402.5 a b$ & $720 a b c$ & 767.3abc & $743.65 a-d$ & $1141 a b c$ & $1118.0 \mathrm{bcd}$ & $1129.5 \mathrm{ab}$ & 11.34a-e & $30.02 \mathrm{abc}$ & $32.46 \mathrm{a}$ & $31.24 a-d$ \\
\hline$T_{8}$ & $417 a b c$ & 409.3ab & 413.15ab & $722 a b c$ & 783.3abc & $752.65 a-d$ & $1140 a b$ & 1186.0ab & $1163.0 \mathrm{a}$ & $11.60 \mathrm{a}-\mathrm{d}$ & $31.67 a b$ & $32.04 a$ & $31.86 \mathrm{abc}$ \\
\hline$T_{9}$ & $440 a b c$ & $370.0 a-d$ & 405.0ab & $747 a b c$ & $785.3 a b c$ & $766.15 a-d$ & $1187 a b$ & 1155.0abc & $1171.0 \mathrm{a}$ & $12.60 a-d$ & $32.97 a b$ & $29.44 a-d$ & $31.21 a-d$ \\
\hline$T_{10}$ & 447ab & $287.3 e$ & $367.15 b c$ & $623 b c$ & $784.0 \mathrm{abc}$ & 703.5ef & $1080 a b c$ & 871.3efg & 975.56de & $10.97 \mathrm{cde}$ & $29.99 a b c$ & 24.20 cde & 27.10def \\
\hline $\mathrm{T}_{11}$ & $511 a$ & $354.7 b-e$ & $432.85 \mathrm{ab}$ & $650 a b c$ & $745.0 \mathrm{abc}$ & $697.5 \mathrm{~cd}$ & $1161 a b$ & $1100.0 \mathrm{bcd}$ & $1130.5 a$ & 12.24abc & $32.25 a b$ & $30.54 a b c$ & $31.40 \mathrm{a}$ \\
\hline$T_{12}$ & $447 a b c$ & $437.3 a$ & $442.15 a$ & $804 a$ & $846.0 \mathrm{a}$ & $825.0 \mathrm{a}$ & $1251 a$ & $1283.0 \mathrm{a}$ & $1267.0 \mathrm{a}$ & $13.10 \mathrm{a}$ & $34.75 a$ & $35.65 a$ & $35.20 \mathrm{a}$ \\
\hline$T_{13}$ & $282 \mathrm{~cd}$ & $280.7 \mathrm{e}$ & $281.35 d$ & $693 a b c$ & $509.3 f$ & $601.0 \mathrm{ef}$ & $978 b c$ & $764.7 \mathrm{~g}$ & $871.35 \mathrm{e}$ & $11.00 \mathrm{~b}-\mathrm{e}$ & $27.17 b c$ & $21.24 \mathrm{e}$ & $24.21 \mathrm{ef}$ \\
\hline $\mathrm{T}_{14}$ & $351 a-d$ & $340.0 \mathrm{de}$ & $345.5 \mathrm{~cd}$ & $736 a b c$ & $613.3 \mathrm{e}$ & $674.65 \mathrm{~cd}$ & $1087 a b c$ & 917.3ef & $1002.2 \mathrm{~cd}$ & $12.15 \mathrm{a}-\mathrm{d}$ & $30.19 a b c$ & $25.48 b-d$ & $27.84 c$ \\
\hline $\begin{array}{l}\text { CV } \\
(\%)\end{array}$ & 8.41 & 9.54 & 8.05 & 9.17 & 6.24 & 4.62 & 8.11 & 6.06 & 4.20 & 6.50 & 8.10 & 9.33 & 5.62 \\
\hline
\end{tabular}

Note: * Pooled of 2001-02 and 2002-03.

Table 5. Single effect of N, P, K and cowdung on the yield of Panchamukhi Kachu

\begin{tabular}{|c|c|c|c|c|c|}
\hline Nutrients added & $\begin{array}{l}\text { Average yield } \\
\text { of two years } \\
\text { (t/ha) }\end{array}$ & $\begin{array}{l}\text { Yield } \\
\text { increase over } \\
\text { control (\%) }\end{array}$ & $\begin{array}{l}\text { Nutrients/ } \\
\text { Organic } \\
\text { manure added }\end{array}$ & $\begin{array}{c}\text { Average } \\
\text { yield of two } \\
\text { years (t/ha) }\end{array}$ & $\begin{array}{l}\text { Yield } \\
\text { increase over } \\
\text { control }(\%)\end{array}$ \\
\hline \multicolumn{3}{|l|}{$\begin{array}{l}\text { Nitrogen } \\
(\mathrm{kg} \mathrm{N} / \mathrm{ha})\end{array}$} & \multicolumn{3}{|l|}{$\begin{array}{l}\text { Potassium } \\
\left(\mathrm{kg} \mathrm{K}_{2} \mathrm{O} / \mathrm{ha}\right)\end{array}$} \\
\hline 0 & 24.28 & - & 0 & 27.10 & - \\
\hline 50 & 28.89 & 15.96 & 60 & 31.40 & 13.69 \\
\hline 100 & 32.57 & 25.42 & 120 & 32.57 & 16.79 \\
\hline 150 & 32.84 & 26.05 & 180 & 35.20 & 23.01 \\
\hline \multicolumn{3}{|l|}{$\begin{array}{l}\text { Phosphorous } \\
\left.\text { (kg } \mathrm{P}_{2} \mathrm{O}_{5} / \mathrm{ha}\right)\end{array}$} & \multicolumn{3}{|l|}{$\begin{array}{l}\text { Cowdung } \\
\text { (t/ha) }\end{array}$} \\
\hline 0 & 27.38 & - & 0 & 16.15 & - \\
\hline 25 & 31.24 & 12.35 & 20 & 24.21 & 33.29 \\
\hline $\begin{array}{l}50 \\
75\end{array}$ & $\begin{array}{l}31.86 \\
32.57\end{array}$ & $\begin{array}{l}14.06 \\
15.93\end{array}$ & 30 & 27.84 & 41.98 \\
\hline 100 & 31.21 & 12.27 & & & \\
\hline \multicolumn{6}{|c|}{$\begin{array}{l}\text { Table 6. Partial budget and dominance analysis for the different fertilizer treatments tested } \\
\text { on Panchamukhi Kachu }\end{array}$} \\
\hline Treatments & $\begin{array}{l}\text { Average yield of } \\
\text { two years }(\mathrm{t} / \mathrm{ha})\end{array}$ & $\begin{array}{l}\text { Gross return } \\
\text { ('000' Tk./ha) }\end{array}$ & $\begin{array}{l}\text { Variable cost } \\
\text { ('000' Tk./ha) }\end{array}$ & $\begin{array}{l}\text { Gross margin } \\
\text { ('000' Tk./ha) }\end{array}$ & Remarks \\
\hline $\mathrm{T}_{1}{ }^{*}$ & 16.15 & 161.5 & 45.00 & 116.50 & CUD \\
\hline $\mathrm{T}_{2}$ & 24.28 & 242.8 & 55.39 & 187.41 & $C D$ \\
\hline $\mathrm{T}_{3}$ & 28.89 & 288.9 & 56.05 & 232.85 & $C D$ \\
\hline $\mathrm{T}_{4}$ & 32.57 & 325.7 & 5670 & 269.00 & CUD \\
\hline$T_{5}$ & 32.84 & 328.7 & 57.35 & 271.05 & CUD \\
\hline $\mathrm{T}_{6}$ & 27.38 & 273.8 & 53.90 & 219.90 & CUD \\
\hline $\mathrm{T}_{7}$ & 31.24 & 312.4 & 63.74 & 248.66 & $C D$ \\
\hline
\end{tabular}


Effect of $\mathrm{N}, \mathrm{P}, \mathrm{K}$ and cowdung on the growth and yield of panchamukhi kachu

\begin{tabular}{cccccc}
\hline Treatments & $\begin{array}{c}\text { Average yield of } \\
\text { two years (t/ha) }\end{array}$ & $\begin{array}{c}\text { Gross return } \\
\text { ('000' Tk./ha) }\end{array}$ & $\begin{array}{c}\text { Variable cost } \\
\text { ('000' Tk./ha) }\end{array}$ & $\begin{array}{c}\text { Gross margin } \\
\text { ('000' Tk./ha) }\end{array}$ & Remarks \\
\hline \hline $\mathrm{T}_{8}$ & 31.86 & 318.6 & 64.67 & 253.93 & $\mathrm{CD}$ \\
$\mathrm{T}_{9}$ & 31.21 & 312.1 & 66.53 & 245.57 & $\mathrm{CD}$ \\
$\mathrm{T}_{10}$ & 27.10 & 271.0 & 54.10 & 216.90 & $\mathrm{CD}$ \\
$\mathrm{T}_{11}$ & 31.40 & 314.0 & 55.40 & 258.60 & $\mathrm{CUD}$ \\
$\mathrm{T}_{12}$ & 35.20 & 352.0 & 58.00 & 294.00 & $\mathrm{CUD}$ \\
$\mathrm{T}_{13}$ & 24.21 & 242.1 & 55.00 & 187.10 & $\mathrm{CD}$ \\
$\mathrm{T}_{14}$ & 27.84 & 278.4 & 60.00 & 218.40 & $\mathrm{CD}$ \\
\hline
\end{tabular}

Note: ${ }^{*}$ As in Table 1, CUD $=$ Cost Undominated, CD = Cost Dominated

Price of - Panchamukhi kachu $=$ Tk. 10.00/kg, Urea $=$ Tk. 6/kg-N, TSP $=$ Tk. 17.00/kg- $\mathrm{P}_{2} \mathrm{O}_{5}, \mathrm{MP}=\mathrm{Tk} .13 .00 / \mathrm{kg}-\mathrm{K}_{2} \mathrm{O}$, Cowdung $(\mathrm{Cd})=$ Tk. $0.50 / \mathrm{kg}$

Table 7. Marginal analyses of cost undominated fertilizer treatments tested on Panchamukhi Kachu

\begin{tabular}{lccccc}
\hline $\begin{array}{l}\text { CUD } \\
\text { Treatment }\end{array}$ & $\begin{array}{c}\text { Variable cost } \\
\text { ('000' Tk.) }\end{array}$ & $\begin{array}{c}\text { Gross margin } \\
\text { ('000' Tk.) }\end{array}$ & $\begin{array}{c}\text { Marginal } \\
\text { variable cost } \\
\text { ('000' Tk.) }\end{array}$ & $\begin{array}{c}\text { Marginal return } \\
\text { ('000' Tk.) }\end{array}$ & $\begin{array}{c}\text { Marginal rate } \\
\text { of return } \\
\text { (MRR \%) }\end{array}$ \\
\hline \hline $\mathrm{T}_{12}$ & 58.00 & 339.00 & 0.65 & 22.95 & 3530.77 \\
$\mathrm{~T}_{5}$ & 57.35 & 316.05 & 0.65 & 2.05 & 315.38 \\
$\mathrm{~T}_{4}$ & 56.70 & 314.00 & 1.30 & 10.40 & 800.00 \\
$\mathrm{~T}_{11}$ & 55.40 & 303.60 & 1.50 & 38.70 & 2580.00 \\
$\mathrm{~T}_{6}$ & 53.90 & 264.90 & 8.90 & 103.40 & 1161.80 \\
$\mathrm{~T}_{1}$ & 45.00 & 161.50 & - & - & - \\
\hline
\end{tabular}

Note: $\mathrm{T}_{1}=\mathrm{N}_{0} \mathrm{P}_{0} \mathrm{~K}_{0} \mathrm{~kg} / \mathrm{ha}$ and ${ }^{*} \mathrm{CD}_{0} \mathrm{t} / \mathrm{ha}, \mathrm{T}_{4}=\mathrm{N}_{100} \mathrm{P}_{75} \mathrm{~K}_{120} \mathrm{~kg} / \mathrm{ha}$ and $\mathrm{CD}_{10} \mathrm{t} / \mathrm{ha}, \mathrm{T}_{4}=\mathrm{N}_{150} \mathrm{P}_{75} \mathrm{~K}_{120} \mathrm{~kg} / \mathrm{ha}$ and $C D_{10} \mathrm{t} / \mathrm{ha}, \mathrm{T}_{6}=$ $\mathrm{N}_{100} \mathrm{P}_{0} \mathrm{~K}_{120} \mathrm{~kg} / \mathrm{ha}$ and $C D_{10} \mathrm{t} / \mathrm{ha}, \mathrm{T}_{11}=\mathrm{N}_{100} \mathrm{P}_{75} \mathrm{~K}_{60} \mathrm{~kg} / \mathrm{ha}$ and $\mathrm{CD}_{10} \mathrm{t} / \mathrm{ha}, \mathrm{T}_{12}=\mathrm{N}_{100} \mathrm{P}_{75} \mathrm{~K}_{180} \mathrm{~kg} / \mathrm{ha}$ and $C D_{10} \mathrm{t} / \mathrm{ha}$. ${ }^{*} \mathrm{CD}=\mathrm{Cowdung}$.

From the investigation, it is appeared that application of $100 \mathrm{~kg} \mathrm{~N}, 75 \mathrm{~kg} \mathrm{P}_{2} \mathrm{O}_{5}, 180 \mathrm{~kg} \mathrm{~K}_{2} \mathrm{O}$ and 10tons of cowdung /ha are the most suitable fertilizer dose for the production of Panchamukhi Kachu in the south-eastern hilly region of Bangladesh (AEZ-29).

\section{LITERATURE CITED}

Ahmed, G. and Rashid, M. M. 1975. A comparative study of the gross morphological characters and the yield potentialities of the major types of edible aroids of Bangladesh. Bangladesh Hort 3(1), 15-21.

Ahmed, K. U. and Shahjahan, M. 1993. Homestead Vegetable Production Training Manual. On-Farm Research Division, Bangladesh Agricultural Research Institute, Joydebpur, Gazipur. p. 87.

Anonymous. 1969. International Soil Fertility Evaluation and Improvement Program. Technical Bulletin No. 5. North Carolina State University, USA.

Bose, T. K. and Som, M. G. 1986. Vegetable crops in India. Ist Ed ${ }^{n}$. Prokash, Bidan Sarani, Calcutta. p. 728.

Mannan, M. A. and Rashid, M. M. 1983. Effect of spacing and mulching on the yield of Pancha-mukhi Kachu (Colocasia esculenta). Bangldesh J Agric Res 8(2), 69-73.

Mitra, S. K., Sadhu, M. L. and Bose, T. K. 1990. Nutrition of Vegetables Crops. Nayaprakash, Calcutta, 700006, India. pp. 157-159.

Perrins, R. K., Winkelman, D. L., Moscardi, E. R. and Anderson, J. R. 1979. Economic Training Manual. Information Bull No. 27, CIMMIT, Mexico.

Rashid, M. M. 1999. Shabji biggayan (in Bengali). Rashid pub. house, 94 old DOHS, Dhaka- 1206. p. 454.

Zahirul, A. T. S. 1991. Inventory of soil fertility status of Agricultural Research Station, Hill Farming- Report 8, ARS, Raikhali Rangamati. p. 2. 